April 25, 2012

Mr. Bryan Werner

Pennsylvania Bureau of Radiation Protection

Rachael Carson Office Building

P.O. Box 8469

Harrisburg, PA 17105-8489

\title{
SUBJECT: COMMENTS ON RESIDENT FARMER DCGLS FOR SITE SOILS AT THE CUR'TISS-WRIGHT SITE IN CHESWICK, PENNSYLVANIA DCN: 5000-TR-04-0
}

Dear Mr. Werner:

As requested, the Oak Ridge Associated Universities, via the Oak Ridge Institute for Science and Education contract, evaluated the resident farmer derived concentration guideline levels report for soils at the Curtiss-Wright Electro-Mechanical Corporation facility in Cheswick, Pennsylvania. Comments identified as a result of the evaluation are enclosed for your consideration. Please contact me at 865.574 .0685 or Erika Bailey at 865.576.6659 should you have any questions or require additional information.

Sincerely,

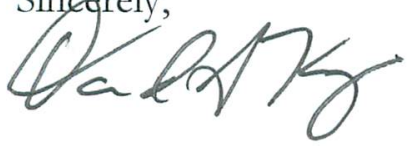

David King, CHP

Project Manager/Sr. Health Physicist

IEAV/Survey Projects

DK:fr

Enclosure

$$
\text { cc: } \quad \text { File } / 5000
$$

electronic distribution: S. Roberts, ORISE

T. Vitkus, ORISE

E. Bailey, ORISE

\begin{tabular}{|l|l|}
\hline Distribution approval and concurrence: & Initials \\
\hline Technical Review & \\
\hline Group Manager & \\
\hline
\end{tabular}




\section{COMMENTS ON DCGLS FOR SITE SOILS AT THE CURTISS-WRIGHT SITE IN CHESWICK, PENNSYLVANIA}

As requested, Oak Ridge Associated Universities (ORAU), via the Oak Ridge Institute for Science and Education contract, evaluated the Enercon Services, Inc. report on site soils derived concentration guideline levels (DCGLs) (Enercon 2012). These DCGLs were calculated based on the Title 10 Code of Federal Regulations Part 20, Subpart E dose limit of $25 \mathrm{mrem} / \mathrm{yr}$ and a resident farmer exposure scenario, and after considering comments prepared by ORAU (ORAU 2010) on the 2009 report (Enercon 2009). The RESRAD code Version 6.5 was used in deterministic mode to consider a range of radionuclides and potential future receptors. A standard sensitivity analysis was also included, along with a probabilistic analysis to select conservative input values for the most sensitive physical parameters.

Overall DCGL calculations are conservative and provided materials are comprehensive and cohesive. ORAU could not open RESRAD files but - with the exception of $25^{\text {th }}, 50^{\text {th }}$, and $75^{\text {th }}$ percentile values - outputs could be verified to match input and result tables.

\section{SPECIFIC COMMENTS}

Table 4.1. Note it is conservative, though common, to assign the lowest calculated DCGL regardless of the year of maximum exposure. ORAU suggests adding the year of maximum exposure to the table.

The C-14 DCGL result is troublesome. At first glance it appears odd that only Sr-90 and Th-232 are more radiotoxic. The RESRAD report indeed shows the year-0 C-14 dose rate of $9.4 \mathrm{mrem} / \mathrm{yr}$, which then drops to essentially $0(<0.001 \mathrm{mrem} / \mathrm{yr})$ in three years. This means that for the exposure to occur the soil would have to be freshly contaminated near the end of the facility's lifecycle, the land quickly transferred to the public, and a subsistence farm quickly established before the C-14 disappears. Perhaps this is how RESRAD deals with C-14 (e.g., via evapotranspiration), but it seems impossible to have a complete exposure pathway. If C-14 is measured at the site, there is either a continuous C-14 source or the model is grossly unrealistic.

Section 5.2. It appears area factors will only be calculated for a $1-\mathrm{m}^{2}$ area. ORAU suggests the contractor consider a range of potential surface areas ranging up from this minimum value, although 
significant differences for areas over a few thousand $\mathrm{m}^{2}$ are not expected. Alternatively, if the site plans an as low as reasonably achievable (ALARA) goal of cleaning up any locations of residual contamination greater than $1 \mathrm{~m}^{2}$, this should be stated; otherwise a more complete area factor table is desirable.

Section 6. The text suggests potential issues with low DCGL values, specifically noting that the $1.6 \mathrm{pCi} / \mathrm{g}$ value for Th-232 is nearly equal to the average (assumed) background concentration. DCGLs are limits in excess background; thus if the average background concentration in soil is $1.5 \mathrm{pCi} / \mathrm{g}$, the gross Th-232 DCGL is $3.1 \mathrm{pCi} / \mathrm{g}$. The sum-of-fractions approach should include background subtraction.

Also, the summary proposes a potential issue with the $3.7 \mathrm{pCi} / \mathrm{g}$ DCGL for I-129 compared to "the normal detection limit for soils... in the range of $20 \mathrm{pCi} / \mathrm{g}$." Standard methods can be used to achieve I-129 detection limits less than the DCGL. For example, the ORAU laboratory can achieve $<2$ pCi/g using a 1-hour count. Low Energy Photo Spectroscopy can also be used to lower detection limits.

Table D-1. Is the well pump rate of $2,426 \mathrm{~m}^{3} / \mathrm{yr}$ physically possible? If not, the parameter could be adjusted and DCGLs revised accordingly. If there is insufficient water to fully supply the farm, that fact should be considered, though the proposed conservative approach is not unacceptable.

RESRAD Files. ORAU could not open the RESRAD files (FORTRAN error), but parameter adjustments based on the sensitivity analysis appear consistent with expected values. Flat files for select radionuclides were thoroughly reviewed including Am-241, Cs-137, Pu-239, U-235, and U-238. No inconsistencies were encountered and results appear correctly transferred to report tables. All values in Table 4-1 were confirmed.

Distribution coefficients for long-lived decay products are default values, but the value for target contaminants are from the uncertainty analysis. For example, the coefficient for $\mathrm{Pu}-241$ is set to the $50^{\text {th }}$ percentile value per the uncertainty analysis but the long-lived decay product Am-241 (another potential contaminant) is set to RESAD default. The calculated Am-241 coefficient is $\sim 1445 \mathrm{~cm}^{3} / \mathrm{g}$ per Table F-1, while the RESRAD default is $20 \mathrm{~cm}^{3} / \mathrm{g}$. This is a significant difference with potential dose and DCGL ramifications. 


\section{REFERENCES}

ENERCON 2009. DCGLs for Site Soils, Volume 1 and 2. ENERCON Services, Inc. Curtiss-Wright Electro-Mechanical Corporation. Cheswick, Pennsylvania. January 8.

ENERCON 2012. Remediation Criteria Curtiss-Wright Flow Control Company, Cheswick, PA - Soil $D_{C G L}$ Calculations. ENERCON Services, Inc. Prepared for Curtiss-Wright Flow Control Company. Cheswick, Pennsylvania. March 6.

ORAU 2010. Comments on Soil DCGLs for Site Soils at the Curtiss-Wright Site in Cheswick, Pennsylvania. Oak Ridge Associated Universities. DCN 5000-TR-03-0. Prepared for the Pennsylvania Bureau of Radiation Protection. November 22. 